\title{
Effects of Xylitol on Nitrogen, Water and Electrolyte Metabolism in Fasted Rabbits
}

\author{
ToshiJi Igarashi, Masatoshi Kobayashi, Tadao ShoJI, \\ Yoshio Tanabe, Keitchi Nomura and Shinzaburo OHtake \\ Department of Pharmacology, Section of Experimental The- \\ rapeutics Research, Research \& Development Division Eisai \\ Co., Ltd., Tokyo
}

Igarashi, T., Kobayashr, M., ShoJI, T., Tanabe, Y., Nomura, K. and OHTake, S. Effects of Xylitol on Nitrogen, Water and Electrolyte Metabolism in Fasted Rabbits. Tohoku J. exp. Med., 1973, 111 (2) 147-155 - The effects of xylitol and glucose infused upon nitrogen, water and electrolyte metabolism were comparatively studied in rabbits. During 10 days' fasting, a daily dosis of $40 \mathrm{ml}$ $/ \mathrm{kg}$ of the following solutions was infused for 4 hours. The animals, which were infused with a multiple balanced electrolyte solution, lost $36 \%$ of body weight during the fasting, accompanied by net losses of $8 \mathrm{~g}$ nitrogen, $160 \mathrm{ml}$ water (excluding insensible water loss), $9 \mathrm{mEq}$ sodium, $28 \mathrm{mEq}$ potassium, $2.5 \mathrm{mEq}$ magnesium and $0.2 \mathrm{mEq}$ calcium per $\mathrm{kg}$ body weight. The animals were emaciated at the terminal stage and two of six animals died. The animals infused with a $5 \%$ glucose solution with balanced electrolyte composition lost $30 \%$ of body weight and one of six animals died. The urinary excretions of nitrogen, sodium and calcium in these animals were significantly less than those in animals receiving the electrolyte solution without carbohydrate. More pronounced sparing effects for nitrogen, water, sodium and potassium were found with a $5 \%$ xylitol solution with balanced electrolyte composition, while the losses of magnesium and calcium were rather promoted. The decrease of body weight in this group was $24 \%$ and none of six animals died. The similar results were also obtained by the infusion of other xylitol solutions with or without electrolyte composition. The sparing effects of glucose were manifested exclusively at the early stage of the fasting, whereas those of xylitol were more pronounced at the late stage when the starvation progressed.____ Fasting; nitrogen balance; water and electrolyte balances; xylitol

When the oral intake of water and nutrients is infeasible, the living body complies with energy requirements through the consumption of glycogen and fat reservoir and ultimately through the combustion of body protein. The infusion of carbohydrate solution in such a circumstance reduces the urinary excretion of nitrogen. This has been called the protein sparing effect of carbohydrate. It is also known that the administration of carbohydrate results in a significant reduction in the rate of water and sodium excretion. This sodium sparing effect cannot be expected from the administration of protein or fat. Gamble (1954) described that the sodium sparing by glucose provides valuable physiological benefit by reducing the loss of extracellular fluid in a state of fasting. 
TABLE 1. Compositions (content per liter) of the solution studied and their abbreviations

\begin{tabular}{lccccc}
\hline & \multicolumn{5}{c}{ Abbreviation of solution } \\
\cline { 2 - 6 } Composition & X & X+S & X+B & B & G+B \\
\hline Xylitol (g) & 50 & 50 & 50 & - & - \\
Glucose (g) & - & - & - & - & 50 \\
Sodium (mEq) & - & 60 & 45 & 45 & 45 \\
Potassium (mEq) & - & - & 25 & 25 & 25 \\
Magnesium (mEq) & - & - & 5 & 5 & 5 \\
Chloride (mEq) & - & 45 & 45 & 45 & 45 \\
Phosphate (mEq) & - & - & 10 & 10 & 10 \\
Acetate (mEq) & - & 15 & 20 & 20 & 20 \\
\hline
\end{tabular}

Xylitol, an intermediate of the glucuronic cycle, has been introduced recently into the treatment with parenteral nutrition. The present study was undertaken to examine whether xylitol is effective as much as glucose in the action to conserve body water and electrolyte in a fasting state.

\section{Materials and Methods}

Adult male rabbits weighing $2.3-2.8 \mathrm{~kg}$ were caged individually one week prior to the beginning of the fasting. Their general condition, body weight, water intake ( $300 \mathrm{ml} /$ day as a maximum), food consumption (Oriental Yeast, RC-5, $120 \mathrm{~g} /$ day as a maximum) and urinary excretion of water and electrolytes were measured throughout this period. Thirty rabbits, which were free of insufficient food intake or abnormalities such as diarrhea, were selected and were divided into five groups at random.

For 10 days' fasting, the animals were kept away from food and water and infused with a daily dose of $40 \mathrm{ml} / \mathrm{kg}$ of the solutions shown in Table 1. The infusion was carried out by drip into ear vein at a constant rate of $0.4 \mathrm{ml} / \mathrm{minute}$. On the 1 st day after the end of the fasting, the animal was given $40 \mathrm{~g}$ of food and $300 \mathrm{ml}$ of water, and then offered food and water in the same amount as before the fasting

The nitrogen concentration in urine was measured by the Rappaport's titration method (Rappaport and Eichhorn 1947). The values obtained by this nitrogen assay method were comparable to those measured by Kjeldahl's method (Fig. 1). The concentrations of sodium and potassium in urine and plasma were determined by using a flame photometer (Hitachi, model 205), and those of magnesium and calcium using an atomic absorption spectrophotometer (Hitachi, model 303).

\section{Results}

\section{General condition and body weight}

Before the fasting, most of the animals consumed all of $120 \mathrm{~g}$ of food and 300 $\mathrm{ml}$ of water per day. The body weights which remained unchanged or tended toward slight gain were decreased with the progress of fasting. The body weight changes are shown in Fig. 2, expressing the weight on the day before the fasting as 100. During the first half of the fasting period, no significant difference was found in the decrease of weight among the groups receiving respective solution. However, the rate of weight loss was remarkably decreased in the animals infused with xylitol solutions, i.e., $\mathrm{X}, \mathrm{X}+\mathrm{S}$ and $\mathrm{X}+\mathrm{B}$ at the latter half of the fasting 




Fig. 1. Comparison of the values obtained by Rappaport' method (on the abscissa) with those by micro-Kjeldahl' method (on the ordinate) in the determination of urinary nitrogen in rabbits.

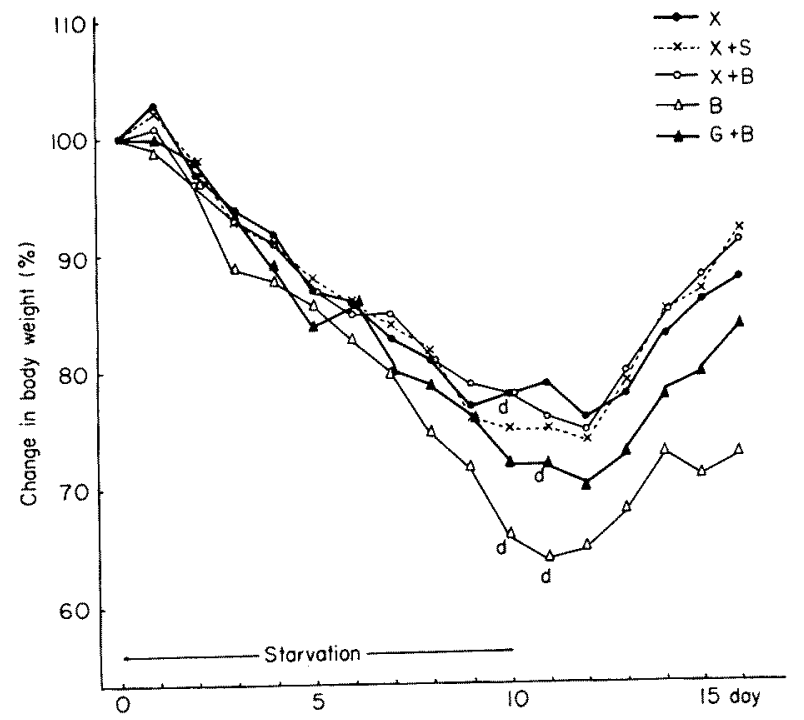

Fig. 2. Body weight changes during and after the fasting. The weight are expressed on the basis of that on the day before the fasting as 100 . During the 10 days' fasting, the animals were infused with $40 \mathrm{ml} / \mathrm{kg} /$ day of the respective solutions, i.e. $\mathrm{B}(\Delta), \mathrm{G}+\mathrm{B}$ $(\bullet), X+B(0), X+S(x)$ and $X(\bullet)$.

period. The mean values of weight loss throughout 10 days' fasting were $36 \%$ in the group $\mathrm{B}, 30 \%$ in the group $\mathrm{G}+\mathrm{B}$ and about $24 \%$ in the groups $\mathrm{X}, \mathrm{X}+\mathrm{S}$ and $\mathrm{X}+\mathrm{B}$. The refeeding induced a rapid gain of the body weight in most of the animals, although some animals in the groups $B$ and $G+B$ were extremely emaciated and showed a delayed recovery.

The animals that died, i.e., two animals in the group B, one in the group $G+B$ 




Fig. 3. Accumulated balances of nitrogen (left) and water (right) during the 10 days' fasting.

and one in the group $X$, had shown a marked decrease of body weight (35-40\% of the weight before the fasting), but no recognizable changes were found at the postmortem examination.

\section{Water balance}

The urine voided in the metabolism cage was collected daily. The overall mean urine volume was in a range of $65-70 \mathrm{ml} / \mathrm{kg}$ before the fasting when the animal drank up $120 \mathrm{ml} / \mathrm{kg}$ water on the average. During the fasting period, the animals received water exclusively by the infusion of the respective solutions. The urine volumes in this period varied greatly day by day, since the frequency of urination markedly decreased. For this reason, the fluctuations of the urinary water-output throughout the fasting period were cumulatively calculated. The water balance was hereupon represented solely by subtracting the urine volume from the amount of the solution infused, since the insensible water loss was not determined. Fig. 3 (right) shows the accumulated water balances in 6 groups throughout the 10 days' fasting period. During the first half of fasting period, there were no differences in the urine volume among the 6 animal groups and the overall mean was around $50 \mathrm{ml} / \mathrm{kg}$. However, the urine volume was progressively increased in the groups $B$ and $G+B$ at the latter half of the fasting period, whereas the volume was markedly decreased in the animals infused with xylitol solutions, particularly the solution $\mathrm{X}$.

\section{Nitrogen balance}

Before the fasting, the nitrogen intake which was estimated from the food consumption was approximately $1.4 \mathrm{~g} / \mathrm{kg}$ per day and the nitrogen output in urine was approximately $1.0 \mathrm{~g} / \mathrm{kg}$. Assuming that the nitrogen output in the feces varied in a range of $0.1-0.2 \mathrm{~g} / \mathrm{kg}$, the animals were considered to have been in a 
state of slightly positive nitrogen balance before the fasting. Since the fecal nitrogen output is relatively small and does not vary so much even in a stage of catabolism (Igarashi et al. 1970), it was not determined in the present study. The nitrogen output means herein the excretion of nitrogen only in the urine, and the values are equal with the amounts of negative nitrogen balances during the fasting, because the animal received no nitrogen source by the infusion.

The accumulated nitrogen balances throughout the fasting are shown on the left side of Fig. 3. Within the first few days of fasting, the nitrogen outputs were decreased to a level of $0.5 \mathrm{~g} / \mathrm{kg}$ in each group. However, the nitrogen outputs in the groups $\mathrm{B}$ and $\mathrm{G}+\mathrm{B}$ were progressively increased thereafter, reaching a higher level than $1.0 \mathrm{~g} / \mathrm{kg}$ at the end of fasting period. In contrast, little or no increase in the nitrogen output was found in the animals infused with the xylitol solutions even on the 10th fasting day. To sum up, the mean values of net nitrogen losses during the 10 days' fasting were $7.7 \mathrm{~g} / \mathrm{kg}$ in the group $\mathrm{B}, 6.2 \mathrm{~g} / \mathrm{kg}$ in the group $\mathrm{G}+\mathrm{B}, 5.0 \mathrm{~g} / \mathrm{kg}$ in the group $\mathrm{X}+\mathrm{B}, 5.3 \mathrm{~g} / \mathrm{kg}$ in the group $\mathrm{X}+\mathrm{S}$ and $4.7 \mathrm{~g} / \mathrm{kg}$ in the group $X$.

On the 2nd day of refeeding, the nitrogen balance was in equilibrium in the animals infused with the xylitol solutions, whereas it remained negative in the animals of the groups $B$ and $G+B$. The animals in the groups $B$ and $G+B$ were in a catabolic state for 4-6 days after the end of fasting, i.e., the nitrogen output was increased to a level of $1.4 \mathrm{~g} / \mathrm{kg}$ at peak.

\section{Electrolyte balance}

The electrolyte balances during the fasting are cumulatively shown in Figs. 4 and 5 .

Sodium: The animals in the groups $\mathrm{B}, \mathrm{G}+\mathrm{B}$ and $\mathrm{X}+\mathrm{B}$ were daily supplied with $1.8 \mathrm{mEq} / \mathrm{kg}$ of sodium by the infusion of respective solutions during the fasting. Although the sodium excretions in the respective groups exceeded the amounts of infused sodium, the degree of negative balance was significantly slight in the groups $G+B$ and $X+B$. There was a remarkable difference between the two carbohydrates in the time course of the action; namely, the infusion of glucose solution reduced the sodium excretion at the early stage of the fasting, whereas the effect of xylitol was distinct when the starvation progressed.

The net loss of sodium throughout the fasting was $9.5 \mathrm{mEq} / \mathrm{kg}$ in the group B, $7.7 \mathrm{mEq} / \mathrm{kg}$ in the group $\mathrm{G}+\mathrm{B}$ and $6.0 \mathrm{mEq} / \mathrm{kg}$ in the group $\mathrm{X}+\mathrm{B}$. Since the solution $\mathrm{X}$ contained no electrolytes, the sodium excretion in the group $\mathrm{X}$ immediately resulted in the negative balance. The animals in the group $X+S$ were supplied with $2.4 \mathrm{mEq} / \mathrm{kg}$ sodium. The effects of the solutions $\mathrm{X}$ and $\mathrm{X}+\mathrm{S}$ on the sodium excretion were comparable to that of the solution $\mathrm{X}+\mathrm{B}$, i.e., the excretions were gradually decreased to $1 / 10$ of the initial level at the end of fasting.

Potassium: The animals in the groups $\mathrm{B}, \mathrm{G}+\mathrm{B}$ and $\mathrm{X}+\mathrm{B}$ were supplied with $1.0 \mathrm{mEq} / \mathrm{kg}$ of potassium by the infusion of respective solutions. The urinary 




Fig. 4. Accumulated balances of sodium (left) and potassium (right) during the 10 days' fasting.

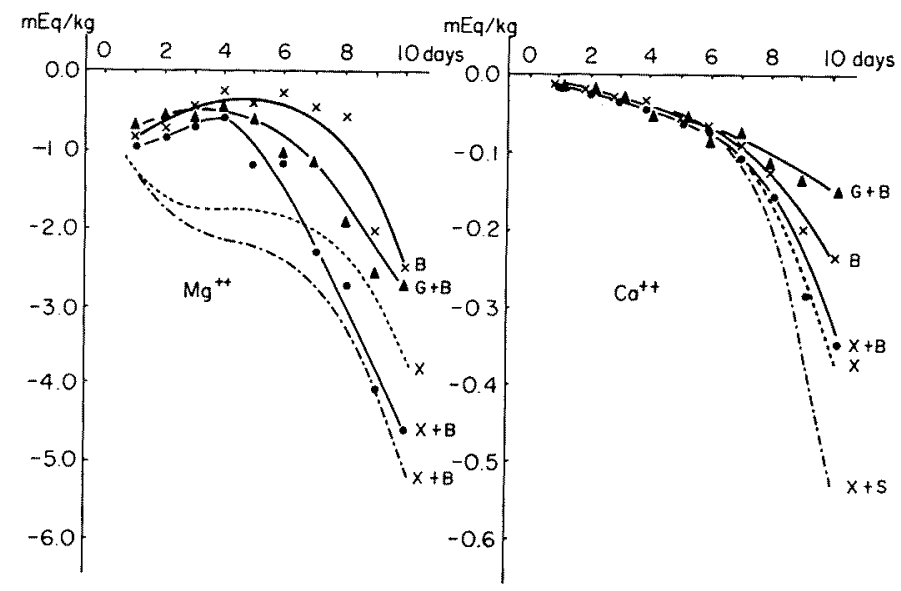

Fig. 5. Accumulated balances of magnesium (left) and calcium (right) during the 10 day's fasting.

excretions of potassium in the groups $B$ and $G+B$ were increased in the latter half of the fasting period. The net loss of potassium was $28 \mathrm{mEq} / \mathrm{kg}$ in the group $\mathrm{B}, 25 \mathrm{mEq} / \mathrm{kg}$ in the group $\mathrm{G}+\mathrm{B}$ and $20 \mathrm{mEq} / \mathrm{kg}$ in the group $\mathrm{X}+\mathrm{B}$. The animals in the groups $\mathrm{X}$ and $\mathrm{X}+\mathrm{S}$ were not supplied with potassium. They excreted the same amount of potassium as the animals in the group $\mathrm{X}+\mathrm{B}$ did.

Magnesium and calcium: The animals excreted approximately $1 \mathrm{mEq} / \mathrm{kg}$ of magnesium on the 1st day of the fasting. The magnesium excretions were thereafter decreased to a lower level than the amount of $0.2 \mathrm{mEq} / \mathrm{kg}$ which was supplied with the solutions $\mathrm{B}, \mathrm{G}+\mathrm{B}$ and $\mathrm{X}+\mathrm{B}$. The excretions were progressively increased at the terminal stage of fasting period, particularly in the animal infused with the xylitol solutions. 
None of the solutions used for infusion in these experiments contained calcium. The calcium excretion, which was about 1/10 of the excretion of magnesium before the fasting, was progressively increased at the latter half of the fasting period. The infusion of glucose reduced the calcium excretion, whereas that of xylitol increased the excretion.

\section{Discussion}

In Table 2 are summarized the decrease of body weight and the accumulated net losses of water, nitrogen and electrolyte throughout 10 days' fasting in the animals infused with the solutions $B, G+B$ and $X+B$. These three solutions are in common with each other in the composition of electrolyte. It is considered that the effect of glucose or xylitol on the fasting would be distinct by comparison of three groups which were treated with respective solutions.

TABLE 2. Comparison of effects of glucose and xylitol on the weight loss, the net losses of water, nitrogen and electrolyte during the 10 days' fasting.

\begin{tabular}{llll}
\hline & Group B & Group G+B & Group X+B \\
\hline Body weight & $360 \mathrm{~g} / \mathrm{kg}$ & $300 \mathrm{~g} / \mathrm{kg}$ & $250 \mathrm{~g} / \mathrm{kg} \dagger$ \\
Water & $170 \mathrm{ml} / \mathrm{kg}$ & $165 \mathrm{ml} / \mathrm{kg}$ & $110 \mathrm{ml} / \mathrm{kg} \dagger$ \\
Nitrogen & $7.7 \mathrm{~g} / \mathrm{kg}$ & $6.2 \mathrm{~g} / \mathrm{kg}$ & $5.0 \mathrm{~g} / \mathrm{kg} \dagger$ \\
Sodium & $9.5 \mathrm{mEq} / \mathrm{kg}$ & $7.7 \mathrm{mEq} / \mathrm{kg}^{*}$ & $6.0 \mathrm{mEq} / \mathrm{kg} \dagger$ \\
Potassium & $28 \mathrm{mEq} / \mathrm{kg}$ & $25 \mathrm{mEq} / \mathrm{kg}$ & $20 \mathrm{mEq} / \mathrm{kg} \dagger$ \\
Magnesium & $2.4 \mathrm{mEq} / \mathrm{kg}$ & $2.7 \mathrm{mEq} / \mathrm{kg}$ & $4.6 \mathrm{mEq} / \mathrm{kg}$ \\
Calcium & $0.24 \mathrm{mEq} / \mathrm{kg}$ & $0.15 \mathrm{mEq} / \mathrm{kg} \dagger$ & $0.35 \mathrm{mEq} / \mathrm{kg}$ \\
Mortality & $2 / 6$ & $1 / 6$ & $0 / 6$ \\
\hline
\end{tabular}

*, $\dagger$ : different from the average of group $B$ significantly at $p=0.05$ or 0.01 , respectively.

During the 10 days' fasting, the animals in the group B were intravenously supplied with $400 \mathrm{ml} / \mathrm{kg}$ water and excreted $570 \mathrm{ml} / \mathrm{kg}$ urine. When taking into estimation an arbitrary value of $190 \mathrm{ml} / \mathrm{kg}$ for insensible loss of water, the weight loss of $360 \mathrm{~g} / \mathrm{kg}$ in these animals could be explained by this water loss. The nitrogen loss of $7.7 \mathrm{~g} / \mathrm{kg}$ is indicative of the combustion of approximately $50 \mathrm{~g}$ body protein, when the content of nitrogen in protein was estimated at $16 \%$. The oxidation of this body protein must result in a release of $150 \mathrm{ml} / \mathrm{kg}$ intracellular water ( $3 \mathrm{ml}$ water per $1 \mathrm{~g}$ protein). It could be also expected, from the ratio of $1 \mathrm{~g}$ protein to $0.5 \mathrm{mEq}$ potassium in cell fluid, that the amount of $25 \mathrm{mEq}$ of potassium should be excreted as the result of the protein combustion. It may be concluded therefore that most of losses of water and potassium during the fasting resulted from combusion of body protein, and accordingly that these water and potassium were derived from intracellular fluid.

From the comparison of nitrogen loss in the group B with that in the group $\mathrm{G}+\mathrm{B}$ or $\mathrm{X}+\mathrm{B}$, it could be estimated that $1.5 \mathrm{~g} / \mathrm{kg}$ or $2.7 \mathrm{~g} / \mathrm{kg}$ nitrogen was spared by the infusion of glucose or xylitol. The nitrogen sparing can be explained as the result of reduced combustion of body protein by the supplement of energy 
source with these carbohydrates. It is noteworthy that the infusion of $20 \mathrm{~g} / \mathrm{kg}$ xylitol $(5 \%$ solution $\times 40 \mathrm{ml} / \mathrm{kg} \times 10$ days) spared approximately $17 \mathrm{~g} / \mathrm{kg}$ protein during the fasting. This finding suggests that the intravenously infused xylitol was utilized to conserve the body protein up to $85 \%$, which is just twice as high as the value in the case of glucose. As mentioned above, this gives a definite explanation for the potent suppressing effects of xylitol on the water and potassium excretion.

One of the distinct differences in the mode of action between glucose and xylitol was seen at the stage of manifestation of actions. The sodium sparing effect was the typical one. The sodium loss in the early phase of starvation was markedly reduced by the infusion of glucose, whereas the sodium excretion in the animals infused with the xylitol solution was decreased to the level less than the amount of sodium supplement at the terminal stage of fasting.

Administration of small amount of carbohydrate in a state of fasting results in significant reduction in the rate of sodium excretion (Bloom 1962; Wricht et al. 1963, Veverbrants and Arky 1969). Neither protein nor fat has such an effect (Bloom 1962). Although the mechanisms of sodium retaining by carbohydrate have not been enough delineated, fasting may impose a limit on energy production in the kidney for active transport of sodium (Wricht et al. 1963). It is known that the renal medulla utilizes glucose and that a significant percentage of its energy expenditure involves sodium transport.

There are two possible explanations for the difference in the time course of action of the two carbohydrates. It has been known that glucose utilization is severely disturbed in some situations such as diabetes, surgical interventions, anesthesia and severe starvation (Halmagyi and Israng 1968; Schultis and Geser 1968), whereas some recent studies suggest that xylitol metabolism is not affected by these morbid conditions (Aono et al. 1968; Uekusa et al. 1969). Another possibility may exist that the enzymatic induction caused by repeatedly infused xylitol raises its metabolic capacity (Bässler 1969; Hosoya and Iitoyo 1969).

There are only a few evidences regarding the effects of carbohydrates on metabolism of bivalent cations. Our finding suggests that the administration of xylitol augmented excretion of these cations, especially magnesium. Neither its mechanism nor its implication has been solved. However, it may be of benefit to supply bivalent cations with xylitol for the parenteral nutrition.

\section{Acknowledgments}

We express our thanks to Professor K. Hashimoto and Dr. T. Onodera, Tohoku University School of Medicine, for their helpful criticisms and suggestions in the preparation of the manuscript, and also to Mr. Y. Nakajima, Miss E. Yamaoka and Miss E. Orikasa, Department of Pharmacology, Eisai Co. Ltd., for their technical assistance in this study.

\section{References}

1) Aono, K., Morita, H. \& Goto, E. (1968) Metabolic effects of xylitol infusion during ether anesthesia in man. In: Kohlenhydrate in der dringlichen Infusionstherapie, 
edited by K. Lang, R. Frey \& M. Halmágyi, Springer-Verlag, Berlin-Heidelberg- New York, pp. 52-56.

2) Bässler, K.H. (1969) Adaptive processes concerned with absorption and metabolism of xylitol. In: Pentose and pentitols, edited by B.L. Horecker, K. Lang \& Y. Takagi, Springer-Verlag, Berlin-Heidelberg-New York, pp. 190-196.

3) Bloom, W.L. (1962) Inhibition of salt excretion by carbohydrate. Arch. intern. Med., 109, 80-86.

4) Gamble, J.L. (1954) Chemical Anatomy, Physiology and Pathology of Extracellular Fluid. Harvard University Press, Cambridge, pp. 140-154.

5) Halmágyi, M. \& Israng, H.H. (1968) Auswahl der Kohlenhydrate zur intravenösen Anwendung in der intra- und postoperativen Phase. In: Kohlenhydrate in der dringlichen Infusionstherapie, edited by K. Lang, R. Frey \& M. Halmágyi, SpringerVerlag, Berlin-Heidelberg-New York, pp. 25-29.

6) Hosoya, N. \& Iitoyo, N. (1969) Inducing effect of xylitol in rats. In: Pentose and pentitols, edited by B.L. Horecker, K. Lang \& Y. Takagi, Springer-Verlag, BerlinHeidelberg-New York, pp. 197-200.

7) Igarashi, T., Yamatsu, K., Tajima, T., Tsutsumi, J. \& Shoji, T. (1970) Effects of infusion with carbohydrate-aminoacids solution on the shock states experimentally induced by hemorrhage or burn. Jutsugotaisha Kenkukai shi (Jap.), 4, 13-15.

8) Rappaport, F. \& Eichhorn, F. (1947) Rapid titrimetric micromethod for the determination of nonprotein nitrgoen. J. Lab. clin. Med., 32, 1034-1036.

9) Schultis, K. \& Geser, C.A. (1968) Klinische Untersuchungen über die Anwendung von Kohlenhydraten bei Stresszuständen. In: Kohlenhydrate in der dringlichen Infusionstherapie, edited by K. Lang, R. Frey \& M. Halmágyi, Springer-Verlag, Berlin-Heidelberg-New York, pp. 30-37.

10) Uekusa, M., Tosen, T., Ohba, M., Akamatsu, T., Narahara, N. \& Kodaira, S. (1969) Effect of xylitol administration on levels of blood sugars and plasma free amino acids following abdominal surgery. In: Pentoses and pentitols, edited by B.L. Horecker, K. Lang \& Y. Takagi, Springer-Verlag, Berlin-Heidelberg-New York, pp. 388-398.

11) Veverbrants, E. \& Arky, R.F. (1969) Effects of fasting and refeeding. I. Studies on sodium, potassium and water excretion on a constant electrolyte and fluid intake. J. clin. Endocr., 29, 55-62.

12) Wricht, H.K., Gann, D.S. \& Albertsen, K. (1963) Effect of glucose on sodium excretion and renal concentrating ability after starvation in man. Metabolism, 12, 804811 . 